\title{
ASPSCR1 wt Allele
}

National Cancer Institute

\section{Source}

National Cancer Institute. ASPSCR1 wt Allele. NCI Thesaurus. Code C70992.

Human ASPSCR1 wild-type allele is located in the vicinity of $17 q 25$ and is approximately $40 \mathrm{~kb}$ in length. This allele, which encodes tether containing UBX domain for GLUT 4 protein, plays a role in the regulation of insulin-mediated glucose transport. A chromosomal translocation $\mathrm{t}(\mathrm{X} ; 17)(\mathrm{p} 11 ; \mathrm{q} 25)$ fuses the gene to the TFE3 gene and is associated with alveolar soft part sarcomas. 